\title{
Molluscan assemblages associated with Gigartina beds in the Strait of Magellan and the South Shetland Islands (Antarctica): a comparison of composition and abundance
}

\author{
Sebastián Rosenfeld ${ }^{\mathrm{a}, \mathrm{b}}$, Cristian Aldea ${ }^{\mathrm{c}, \mathrm{d}}$, Jaime Ojeda $\mathbb{1}^{\mathrm{a}}$, Johanna Marambio ${ }^{\mathrm{a}, \mathrm{b}}$, Mathias Hüne ${ }^{\mathrm{e}}$, \\ Jesús S. Troncosof \& Andrés Mansilla ${ }^{\mathrm{a}, \mathrm{b}}$ \\ aLaboratorio de Macroalgas Antárticas y Subantárticas, Universidad de Magallanes, Punta Arenas, Chile; bInstituto de Ecología y \\ Biodiversidad (IEB), Santiago, Chile; 'Departamento de Ciencias y Recursos Naturales, Universidad de Magallanes, Punta Arenas, Chile; \\ dPrograma GAIA-Antártica, Universidad de Magallanes, Punta Arenas, Chile; eFundación Ictiológica, Santiago, Chile; 'Departamento de \\ Ecología y Biología Animal, Facultad de Ciencias del Mar, Universidad de Vigo, Vigo, Spain
}

\section{ABSTRACT}

In this paper we evaluated the composition and abundance of molluscs associated with beds of the red algae Gigartina, located in the South Shetland Islands (Antarctic Peninsula) and the Strait of Magellan (southern Chile). During the summer season of 2013, samples were obtained by scuba diving using a $0.25 \mathrm{~m}^{2}$ quadrat, arranged randomly within the bed. We extracted a total of 15 quadrats per sampling site. For Antarctic Peninsula beds the most abundant species were the bivalve Lissarca miliaris (233 individuals) and the gastropod Laevilacunaria antarctica (94 individuals), while for Strait of Magellan beds the most abundant species was the polyplacophoran Callochiton puniceus (36 individuals). Comparative analysis between the two molluscan assemblages showed significant differences in the faunal composition between the Antarctic Peninsula and Strait of Magellan ( $f=64.474 ; p=0.0001$ ). Therefore, molluscs reported in both areas are characteristic of their respective biogeographic area. Finally, Gigartina species play an important role in the formation of patterns of abundance and diversity of the communities associated with them.

\section{KEYWORDS}

Bivalvia; Gastropoda; Polyplacophora; algae beds; sub-Antarctic; diversity

\section{ABBREVIATIONS} MBP: Magellanic biogeographical province; NMDS: non-metric multidimensional scaling ordination

\section{Introduction}

In the high-latitude MBP (Spalding et al. 2007), extensive macroalgae assemblages grow on hard substrates, between depths of approximately 0 and $20 \mathrm{~m}$ (Mansilla et al. 2013). These communities of macroalgae are characterized mainly by the presence of species of the order Laminariales, such as Macrocystis pyrifera and Lessonia spp. (Mansilla et al. 2014; Rosenfeld et al. 2014). In the Antarctic Peninsula, macroalgae communities are characterized by the presence of species of Desmarestia (Quartino et al. 2005). However, the Rhodophyta algae Gigartina skottsbergii is a characteristic species of the southern tip of South America (Ramírez \& Santelices 1991) and West Antarctica; it is therefore a species from cold-temperate to cold waters. In the sub-Antarctic ecoregion this species is strictly sublittoral and grows on rocky substrate between 5 and $15 \mathrm{~m}$ deep (Ávila et al. 1999). Nevertheless Billard et al. (2015) show that $G$. skottsbergii has two divergent, monophyletic clades that may correspond to two cryptic species, making Gigartina sp. from Antarctica endemic to this area. In Antarctica it may live from the lower intertidal zone (pers. obs.) to shallow depths (Wiencke \& Clayton 2002). Gigartina skottsbergii forms dense sublittoral beds reaching biomasses of about $1773 \mathrm{~g} \mathrm{~m}^{-2}$ and densities of 15 individuals $\mathrm{m}^{-2}$ (Ávila et al. 2004). Besides being primary producers and ecosystem engineers (Christie et al. 2009; Torres et al. 2015), macroalgae beds are important for sustenance of biodiversity because they can alter local environmental conditions (Stachowicz 2001), providing shelter, breeding places and/or food for many species of invertebrates and vertebrates (Ríos et al. 2007; Mansilla \& Ávila 2011; Rosenfeld et al. 2015). Molluscs are one of the most representative and studied groups worldwide of this algae-mollusc interaction (see Vahl 1971; Salas \& Hergueta 1986; Sánchez-Moyano et al. 2000; Rueda \& Salas 2003; Amsler et al. 2015; Martin et al. 2016).

In the MBP, molluscs are one of the most representative and diverse groups of benthic marine environments, with more than 397 species reported (Linse 1999; Valdovinos 1999). Another important feature of Magellanic molluscs is that $35 \%$ of species are endemic to the MBP (Fortes \& Absalao 2011). Among the molluscs, gastropods are the dominant group in terms of number of species, followed by bivalves (Linse et al. 2006; Clarke et al. 2007). Clarke et al. (2007) recorded a total of 549 species of gastropods and 158 bivalves

CONTACT Sebastián Rosenfeld rosenfeld.sebastian@yahoo.com ESekulovic, Laboratorio de Macroalgas Antárticas y Subantárticas, Universidad de Magallanes, Casilla 113-D, Punta Arenas Chile

(4) Supplemental data for this article can be accessed here. 
distributed in the Southern Ocean. Engl (2012) reported 336 species (plus 59 probably undescribed) of shelled gastropod and over 87 bivalves in Antarctic waters. Specifically, in the area of the Antarctic Peninsula, including the South Shetland Islands, the same authors recorded 130 species of molluscs, i.e., low species richness compared to that recorded in the MBP. In more detail, the sublittoral bottoms corresponding to the continental shelf were represented by 85 species of gastropod and 48 bivalves (Linse et al. 2006). In addition, molluscs exhibited several levels of species richness between different areas of the Southern Ocean and adjacent areas, such as the MBP (Linse et al. 2006). However, although in recent years efforts have increased to better understand MBP and Antarctic molluscan biodiversity (Linse 1999; Griffiths et al. 2003; Zelaya 2005; Linse et al. 2006; Clarke et al. 2007; Aldea et al. 2011; Pastorino 2016), few investigations have focused on the ecological interaction between macroalgae and Antarctic molluscs (Amsler et al. 2015).

The main objective of this study was to characterize and compare molluscan assemblages associated with Gigartina skottsbergii beds in the Strait of Magellan and Gigartina sp. from the Antarctic Peninsula. The level of taxonomic affinity between the two provinces was also tested.

\section{Material and methods}

The study area was localized at four sampling sites with G. skottsbergii and Gigartina sp. beds: two in the Strait of Magellan - Punta Santa Maria, located in Tierra del Fuego (53 $21^{\prime}$ S; $70^{\circ} 27^{\prime} \mathrm{W}$ ); Punta Santa
Ana, located $60 \mathrm{~km}$ to the south of Punta Arenas (53 $37^{\prime}$ S; $\left.70^{\circ} 52^{\prime} \mathrm{W}\right)$ - and in the Antarctic Peninsula: Punta Hanna $\left(62^{\circ} 39^{\prime} \mathrm{S} ; 60^{\circ} 35^{\prime} \mathrm{W}\right)$ and Fildes Bay $\left(62^{\circ}\right.$ $12^{\prime} \mathrm{S}$; $58^{\circ} 54^{\prime} \mathrm{W}$ ) (Fig. 1). The samples were obtained by scuba diving between 1 and $10 \mathrm{~m}$ depth in quadrats of $50 \times 50 \mathrm{~cm}$, which were selected randomly within each bed. In each quadrat, all molluscs were collected, and also the substrate, where Gigartina settled, was investigated. The rocks were subsequently scraped to ensure that all the species and specimens were collected. Each macroalgal sample was placed in a plastic bag. In the laboratory, each sample was gently stirred to detach the associated fauna. Once detached, the algae were removed from the bag and their fresh weight measured. Fifteen quadrats were sampled during one dive at each site, resulting in 60 quadrats per site ( 4 sites $\times 15$ quadrats).

Molluscs density was standardized to individuals per gram of algal fresh weight. To determine the faunal composition - and their comparison - univariate and multivariate biodiversity analyses were performed using the Primer version 6.0 statistical package (Clarke \& Gorley 2005). The univariate biodiversity measures calculated for each site were average species richness and average species abundance. Spearman rank correlation analysis was conducted to determine the correlation between mollusc abundance and macroalgal fresh biomass.

To show significant differences in abundance and species richness, including beds from both provinces, a nonparametric Mann-Whitney test was performed, using the Statistica 7.0 statistical package (StatSoft 2004; http://statistica.software.informer.com/7.0/).
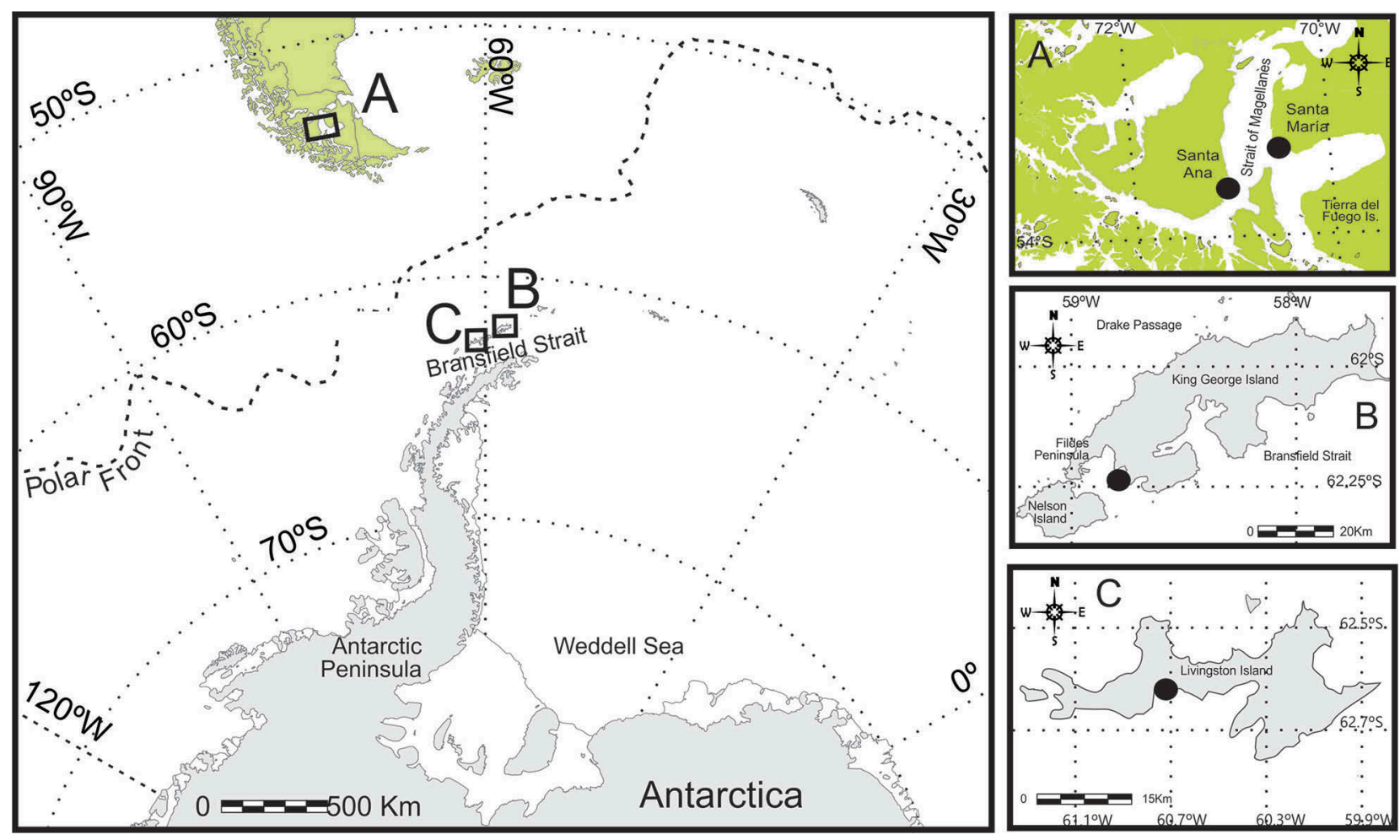

Figure 1. Sampling sites in the Strait of Magellan (A) and South Shetland Islands (B, C). 
The specific importance of each species at each sampling site was determined by the similarity percentage, Simper (Clarke 1993). Once the most representative species of each group was known, complementary NMDS (Kruskal \& Wish 1978) was performed to analyse graphically which species contributed to the similarity of each of the study areas. The data were transformed to presence and absence, to reduce the contribution of abundant species and to equate rare species.

To assess spatial differences in the structure of the assemblages, and as a measure of beta diversity, oneway Permdisp analysis was carried out. Dispersion was calculated as the average dissimilarity from individual observation units to their group centroid in multivariate space (Anderson 2006). Smaller dispersions among the assemblages depicted lower beta diversity.

In order to evaluate the affinity of different taxonomic levels (species, genus, family and order) among the study areas, spatial replacement taxonomic levels (beta diversity) was calculated, i.e., a measure of difference in the composition between two or more assemblages (Koleff 2005). To measure beta diversity, the presence and absence data of molluscan assemblages associated with Gigartina in the Magallanes area and Antarctic Peninsula were considered. In this way, the Whittaker (1972) index was calculated: $\mathrm{DB}=\left(\mathrm{S}_{\mathrm{c}} / \alpha\right)-1$, where $\mathrm{S}_{\mathrm{c}}$ is species richness recorded in a sector set and $\alpha$ is the average number of species in both areas. This index ranges from 0 (when samples are absolutely identical in species composition) and 1 (the samples are absolutely different in their species composition) (Rau et al. 1998).

Finally, we used a linear dependence model to detect whether our sampling effort was able to estimate the total number of species of molluscs. This was designed to estimate species richness, depending on the number of samples (Soberón \& Llorente 1993). All samples were randomized so as not to affect the shape of the curve (Colwell \& Coddington 1994; Moreno \& Halffter 2000). The Simplex and Quasi-Newton estimation methods of the statistical package Statistica 7 were used to estimate the coefficients of the nonlinear regression model.

\section{Results}

We collected a total of 600 specimens and identified 599 individuals to species level. Thirty-five species of molluscs in the classes Polyplacophora, Gastropoda and Bivalvia were represented (Table 1). Of the total, 270 specimens were bivalves, corresponding to 11 species, 254 were gastropods, corresponding to 17 species, and 75 were polyplacophorans, corresponding to seven species. The remaining specimen (the bivalve Hiatella sp.) was not assigned to a known species because we could not identify sufficient diagnostic characters. In terms of the number of species represented, Gastropoda (17 species belonging to nine families) came out on top, followed by Bivalvia (11 species belonging to six families) and Polyplacophora (seven species belonging to four families). The bestrepresented families were Littorinidae (four species) and Phylobryidae (four species).

For Antarctic Peninsula beds, the most abundant species were the bivalve Lissarca miliaris (233 individuals) and the gastropod Laevilacunaria antarctica (94 individuals), while for MBP beds the most abundant species were the polyplacophoran Callochiton puniceus (36 individuals) and the gastropod Fissurella oriens (22 individuals).

Molluscan assemblages from Antarctic Peninsula beds had a higher average abundance $(21.9 \pm 5.6$ individuals) than MBP ones $(7.05 \pm 1.19)$, showing a significant difference between them $(Z=-3.0837$; $p=0.002)$. No significant differences in average species richness were evident $(Z=-1.5959 ; p=0.110)$ between Antarctic assemblages $(4.3 \pm 0.3)$ and MBP ones $(3.70 \pm 0.4)$. We observed a good correlation between Gigartina fresh biomass and the number of associated molluscs measured as total abundance (Gigartina skottsbergii: $r=0.678, p<0.05$; Gigartina sp.: $r=0.616, p<0.05$ ) (Fig. 2).

Simper analysis showed that the cluster of Antarctic Peninsula beds showed an average similarity of $76.31 \%$. Meanwhile, the cluster of MBP beds presented an average similarity of $51.07 \%$. The gastropods Laevilacunaria antarctica and Nacella concinna and the bivalve Lissarca miliaris were the species that most contributed to the similarity of the Antarctic Peninsula assemblages (Fig. 3), while for the MBP assemblages the polyplacophoran Callochiton puniceus and gastropod Fissurella oriens were species that most contributed to their similarity.

NMDS analysis (Fig. 3) revealed that species of both clusters (Antarctic and MBP) were located at a great distance (very low similarity between them). Comparative analysis between the two molluscan assemblages (Permdisp) showed significant differences in the faunal composition between the Antarctic Peninsula and Strait of Magellan $(f=64.474 ; p=0.0001)$.

Turnover of the various taxonomic levels between the assemblages of the Antarctic Peninsula and Strait of Magellan presented a uniform pattern. The species and genus levels had the highest levels of turnover $\left(\beta_{\mathrm{w}}=1\right.$ and 0.8 , respectively). In general, almost all taxonomic levels had high turnover values $\left(\beta_{\mathrm{w}}>0.5\right)$, except at the order level, which had a $\beta_{\mathrm{w}}$ value of 0.1 (Fig. 4).

The species richness associated with the sampling effort was determined by a linear dependence model. For the Antarctic Peninsula, prediction constants were $a=5.3664$ and $b=0.5370$; therefore, the expected maximum richness $(a / b)$ was 10 species with $R^{2}=0.98$ and slope $>0.0000$ (Fig. 5(a)). This value is the same as that observed in the field $(S=10)$. Finally, for the Strait of Magellan, prediction constants were $a=3.1585$ and $b=0.1272$; 
Table 1. Systematic list of all mollusc species recorded, indicating their presence $(+)$ in the beds of Strait of Magellan (MA) and the South Shetland Islands (SI).

\begin{tabular}{|c|c|c|c|}
\hline Class to Family & Species & MA & SI \\
\hline \multicolumn{4}{|l|}{ POLYPLACOPHORA } \\
\hline \multicolumn{4}{|l|}{ Order Chitonia } \\
\hline \multirow[t]{2}{*}{ Ischnochitonidae } & $\begin{array}{l}\text { Ischnochiton stramineus (Sowerby in } \\
\text { Broderip \& Sowerby 1832) }\end{array}$ & + & \\
\hline & Tonicina zschaui (Pfeffer 1886) & & + \\
\hline Callochitonidae & $\begin{array}{l}\text { Callochiton puniceus (Couthouy MS } \\
\text { Gould 1846) }\end{array}$ & + & \\
\hline \multirow[t]{3}{*}{ Chitonidae } & Tonicia lebruni de Rochebrune 1884 & + & \\
\hline & Tonicia chilensis (Frembly 1827) & + & \\
\hline & Tonicia atrata (Sowerby 1840) & + & \\
\hline Mopaliidae & $\begin{array}{l}\text { Nuttallochiton martiali (de Rochebrune } \\
\text { in de Rochebrune \& Mabille 1889) }\end{array}$ & + & \\
\hline \multicolumn{4}{|l|}{ GASTROPODA } \\
\hline \multicolumn{4}{|l|}{ Order } \\
\hline \multicolumn{4}{|l|}{ Patellogastropoda } \\
\hline \multirow[t]{3}{*}{ Nacellidae } & Nacella deaurata (Gmelin 1791) & + & \\
\hline & Nacella flammea (Gmelin 1791) & + & \\
\hline & Nacella concinna (Strebel 1908) & & + \\
\hline Lepetidae & lothia emarginuloides (Philippi 1868) & + & \\
\hline \multicolumn{4}{|c|}{ OrderVetigastropoda } \\
\hline Fissurellidae & Fissurella oriens Sowerby 1835 & + & \\
\hline Calliostomatidae & $\begin{array}{l}\text { Margarella violacea (King \& Broderip } \\
\text { 1832) }\end{array}$ & + & \\
\hline \multicolumn{4}{|l|}{ Order } \\
\hline \multicolumn{4}{|l|}{ Littorinimorpha } \\
\hline Calyptraeidae & Trochita pileus (Lamarck 1822) & + & \\
\hline \multirow[t]{4}{*}{ Littorinidae } & Pellilitorina pellita (Martens 1885) & & + \\
\hline & $\begin{array}{l}\text { Laevilacunaria antarctica (Martens } \\
\text { 1885) }\end{array}$ & & + \\
\hline & $\begin{array}{l}\text { Laevilitorina antarctica (E. A. Smith } \\
\text { 1902) }\end{array}$ & & + \\
\hline & Laevilitorina caliginosa (Gould 1849) & & + \\
\hline Ranellidae & Fusitriton magellanicus (Röding 1798) & + & \\
\hline \multicolumn{4}{|l|}{ Order } \\
\hline \multirow[t]{2}{*}{ Buccinidae } & $\begin{array}{l}\text { Pareuthria cerealis Rochebrune \& } \\
\text { Mabille } 1885\end{array}$ & + & \\
\hline & Pareuthria fuscata (Bruguire 1789) & + & \\
\hline \multirow[t]{3}{*}{ Muricidae } & Trophon pallidus (Broderip 1833) & + & \\
\hline & $\begin{array}{l}\text { Trophon nucelliformis Oliver \& Picken } \\
\quad 1984\end{array}$ & & + \\
\hline & $\begin{array}{l}\text { Xymenopsis muriciformis (King \& } \\
\text { Broderip 1832) }\end{array}$ & + & \\
\hline \multicolumn{4}{|l|}{ BIVALVIA } \\
\hline \multicolumn{4}{|l|}{ Order Pteriomorphia } \\
\hline \multirow[t]{2}{*}{ Mytilidae } & Aulacomya atra (Molina 1782) & + & \\
\hline & Mytilus E platensis d'Orbigny 1842 & + & \\
\hline \multirow[t]{2}{*}{ Pectinidae } & $\begin{array}{l}\text { Zygochlamys patagonica (King \& } \\
\text { Broderip 1832) }\end{array}$ & + & \\
\hline & Austrochlamys natans (Philippi 1845) & + & \\
\hline \multirow[t]{4}{*}{ Phylobryidae } & Philobrya sublaevis Pelseneer 1903 & + & \\
\hline & Philobrya olstadi (Soot-Ryen 1951) & & + \\
\hline & Mysella subquadrata (Pesenner 1903) & & + \\
\hline & Lissarca miliaris (Philippi 1845) & & + \\
\hline \multicolumn{4}{|l|}{ Order Heterodonta } \\
\hline Hiatellidae & Hiatella sp & + & \\
\hline Carditidae & Carditella naviformis (Reeve 1843) & + & \\
\hline Veneridae & Tawera elliptica (Hupé in Gay 1854) & + & \\
\hline Gaimardiidae & Gaimardia trapesina (Lamark 1819) & + & \\
\hline
\end{tabular}

therefore, expected maximum richness $(a / b)$ was 25 species with $R^{2}=0.97$ and slope $=0.069$ (Fig. 5(b)). This value is the same as that observed in the field $(S=25)$.

\section{Discussion}

This is the first comparative report of molluscan assemblages associated with the two Gigartina (a)

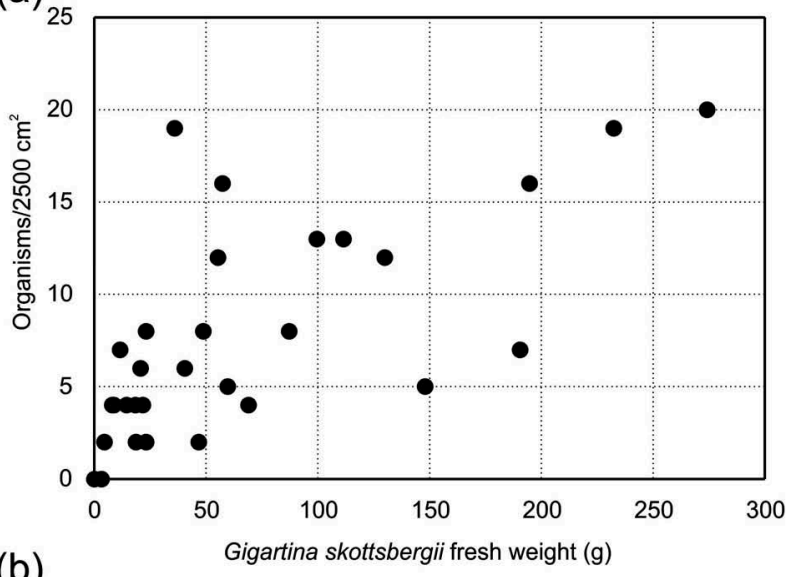

(b)

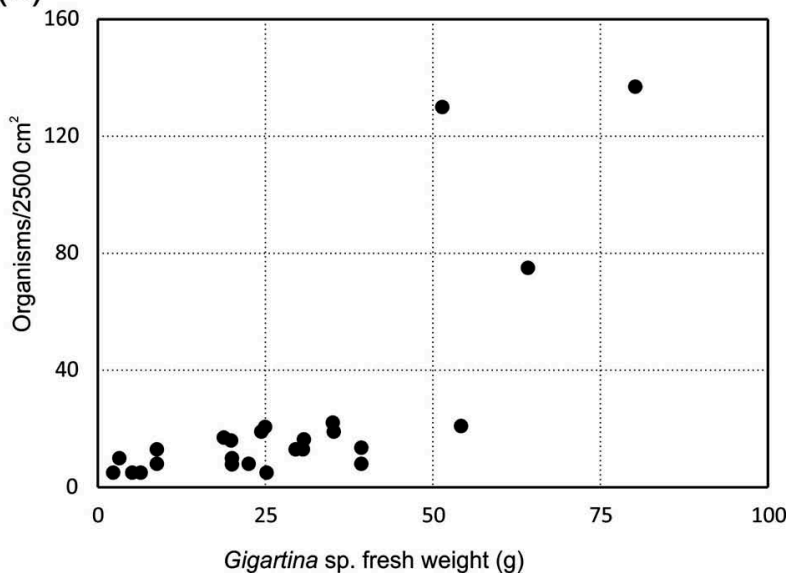

Figure 2. Total abundance of mollusc per macroalgae biomass of Gigartina in the four sampling localities: (a) populations the Strait of Magellan; (b) populations in the South Shetland Islands.

species between the Antarctic Peninsula and Strait of Magellan. For the Strait of Magellan there had already been a previous report by Rosenfeld et al. (2015) and for the Antarctic Peninsula one by Amsler et al. (2015).

The amount of mollusc species recorded in this work represents an average value similar to those reported in other studies carried out over the past 20 years in shallow subtidal rocky environments of the Antarctic Peninsula (Table 2). In this regard, the work with the highest number of species (Amsler et al. 2015) reported a total of 20 species of gastropod associated with Gigartina sp., but that work mainly focused on species of the class Gastropoda. However, in general all the works present a very similar mollusc species richness, being reports of assemblages with low species richness compared with molluscs from shallow subtidal habitats of the MBP, which have an average richness of $35 \pm 13$ species (Rosenfeld et al. 2015). However, although molluscan assemblages from shallow bottoms of the Antarctic Peninsula have lower species richness compared to MBP ones, the level of endemism is higher in assemblages from Antarctica. For example, of the 10 species recorded in 

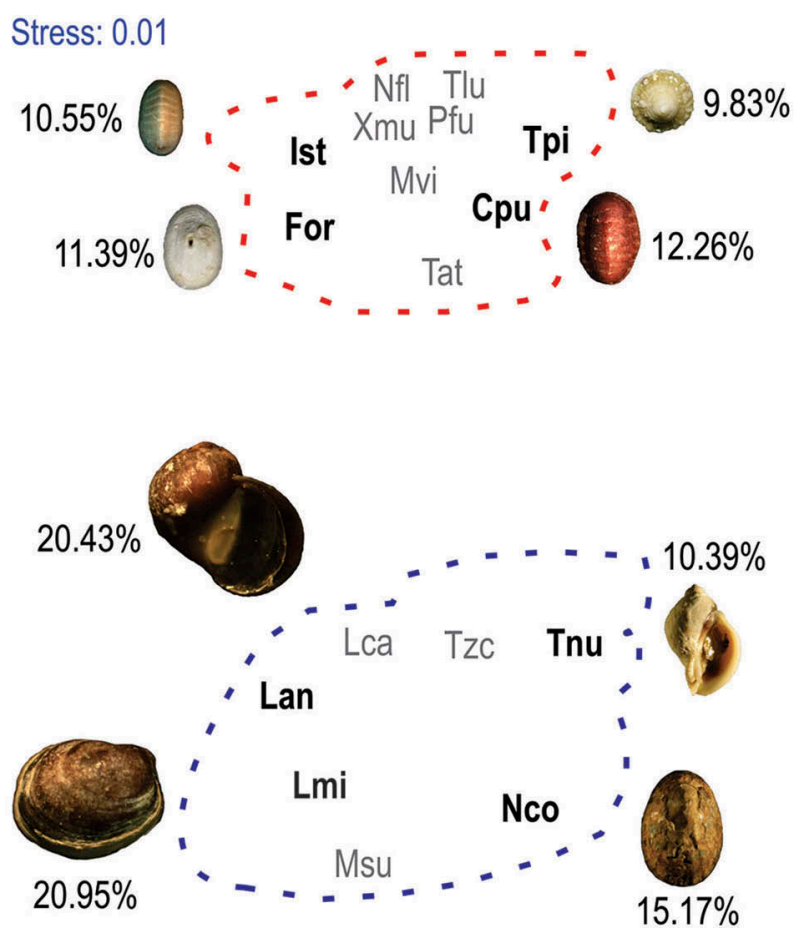

Figure 3. NMDS ordination of molluscan assemblages, showing arrangement of the species that most contributed to the similarity of each of their groups. Cpu (Callochiton puniceus), For (Fissurella oriens), Ist (Ischnochiton stramineus), Lan (Laevilacunaria antarctica), Lca (Laevilitorina caliginosa), Lmi (Lissarca miliaris), Mvi (Margarella violacea), Msu (Mysella subquadrata), Nco (Nacella concinna), Nfl (Nacella flammea), Pfu (Pareuthria fuscata), Tat (Tonicia atrata), Tlu (Tonicia lebruni), Tzc (Tonicina zschaui), Tpi (Trochita pileus), Tnu (Trophon nucelliformis), Xmu (Xymenopsis muriciformis).

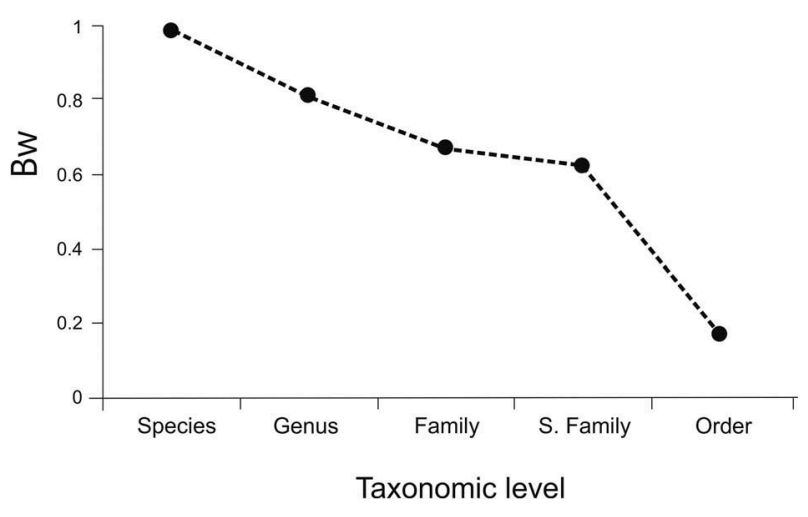

Figure 4. Relationship between taxonomic levels and turnover thereof.

this study, $70 \%$ are endemic to Antarctica, while of the 25 species recorded in the MBP only $28 \%$ are endemic to this biogeographic province (Rosenfeld et al. 2015). These endemism values are related to biogeographic patterns established by Griffiths et al. (2009), who posited that gastropods generally show a high level of endemism in all Antarctic regions. In our study of six species of gastropod registered in Antarctica, only the species Laevilitorina caliginosa reached the MBP, having the Chiloé Islands as a northern distribution boundary (Castellanos 1989).

From our investigation of all previous work, through a full listing of mollusc species, there has been a total of 55 species of mollusc (one
Polyplacophora, 42 Gastropoda and 12 Bivalvia) inhabiting shallow rocky Antarctic environments (0-30 m) (Supplementary Table S1).

As in the work carried out by Jazdzewski et al. (2001) and Martin et al. (2016), the family with the most species in rocky shallow Antarctic environments was Littorinidae. Of the total number of recorded species, nine belong to the Littorinidae family, which could reflect that species of this family are more specialized to these extreme Antarctic environments, where during the winter the sea freezes (Wiencke \& Clayton 2002; Waller et al. 2006). Although, Engl (2012) recorded eight species of Prosipho (family: Buccinidae): P. astrolabiensis (Strebel 1908), P. crassicostatus (Melvill \& Standen 1907), P. glacialis Thiele 1912, P. enricoi Engl 2004, P. harrietae Engl \& Schwabe 2003, P. iodes Oliver \& Picken 1984, P. mundus E. A. Smith 1915, and P. turritus Oliver \& Picken 1984, from rocky shallow waters, none of these species were recorded in the descriptive benthic studies of the last 22 years (Supplementary Table S1). In contrast, in the MBP the most representative family in shallow bottom assemblages was Buccinidae, with more than 10 species (Ríos et al. 2003; Aldea et al. 2011), which may reflect the high diversity presented by this group in the MBP. In the Linse's species checklist of Linse (1999), 27 species of Buccinidae (as Buccinulidae) for the MBP were reported. Another gastropod family 

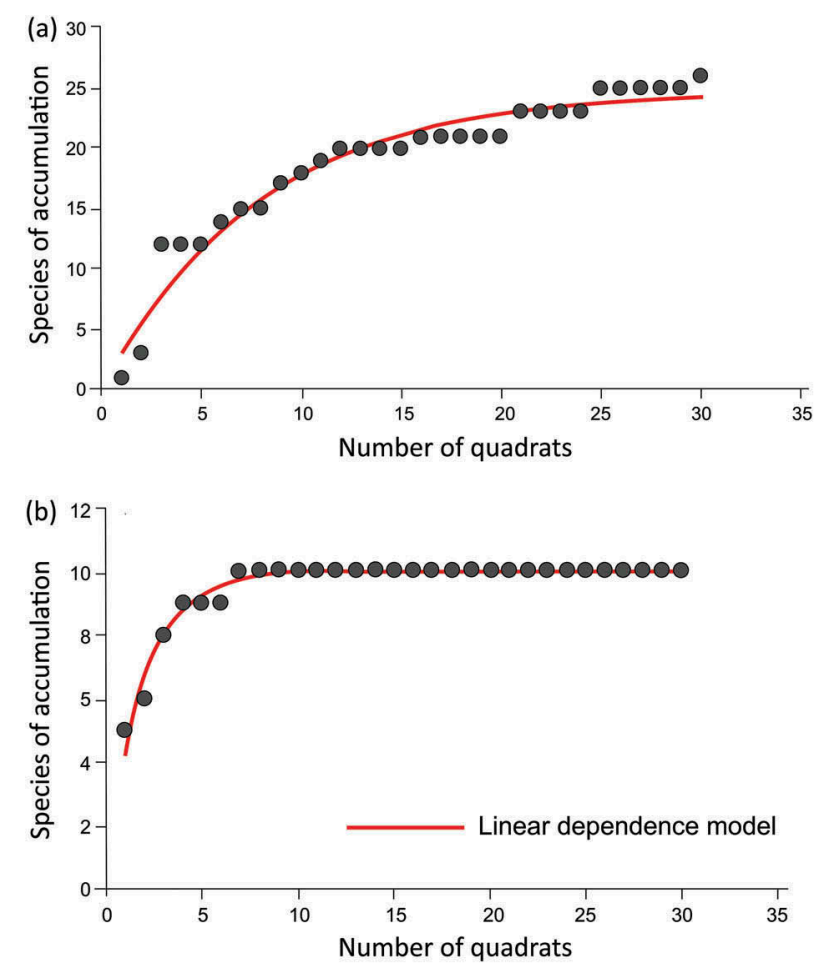

Figure 5. Linear dependence model to estimate the species richness associated with sampling efforts at sampling sites: (a) Strait of Magellan and (b) South Shetland Islands.

Table 2. Number of mollusc species in Antarctica recorded in works since 1994. We took into account studies where intertidal and sublittoral samples were collected (all studies with sampling depths less than $30 \mathrm{~m}$ were included and considered as 'shallow water').

\begin{tabular}{llccc}
\hline Source & \multicolumn{1}{c}{ Depth } & Gastropoda & Bivalvia & Polyplacophora \\
\hline Martin et al. 2016 & $0 \mathrm{~m}$ & 9 & 4 & 0 \\
Bowden 2005 & 8 to ca. $20 \mathrm{~m}$ & 9 & 1 & 0 \\
Waller et al. 2006 & 0 to ca. $6 \mathrm{~m}$ & 6 & 4 & 0 \\
Bick \& Arlt 2013 & $0 \mathrm{~m}$ & 6 & 3 & 0 \\
Gambi et al. 1994 & 0 to ca. $16 \mathrm{~m}$ & 7 & 1 & 0 \\
Jazdzewski et al. 2001 & $0 \mathrm{~m}$ & 5 & 0 & 0 \\
Valdivia et al. 2015 & $0-30 \mathrm{~m}$ & 4 & 3 & 1 \\
Amsler et al. 2015 & $6-16 \mathrm{~m}$ & 20 & 0 & 0 \\
Aghmich et al. 2016 & $0 \mathrm{~m}$ & 7 & 3 & 0 \\
& & $8 \pm 1.7$ & $2.1 \pm 1.7$ & 0 \\
This record & 0 to ca. $7 \mathrm{~m}$ & 6 & 3 & $0.11 \pm 0.4$ \\
\hline
\end{tabular}

representative in the MBP is Calliostomatidae. Linse (1999) used the name Trochidae to group all species of Calliostomatidae, reporting 16 species for the MBP. This group of gastropods is characterized as representative in subtidal studies of the Strait of Magellan (see Ríos et al. 2003; Aldea et al. 2011; Rosenfeld et al. 2015). For example, Calliostomatidae species such as Margarella violacea have been reported as the most abundant (Aldea et al. 2011), as in this study, in which $M$. violacea was one of the representative MBP species (Fig. 6). Regarding polyplacophorans, it should be noted that for the Strait of Magellan assemblage, six species were recorded inhabiting beds of Gigartina, while for the Antarctic Peninsula we only recorded one species (Tonicina zschaui), and generally in work on shallow environments of Antarctica no polyplacophoran species are reported. Therefore, polyplacophorans showed a drastic reduction in species richness compared to the MBP.

The affinity of molluscs at species level between the Strait of Magellan and South Shetland Islands is quite low (Linse et al. 2006). However, these authors mentioned that at higher taxonomic levels (e.g., families) the affinity increases. Nevertheless, in this study we observed that even replacement at superfamily level between assemblages is high $\left(\beta_{\mathrm{w}}=0.6\right)$; therefore, molluscs reported in both areas are characteristic of their respective biogeographic area.

Finally, we note that in shallow-bottom systems in Antarctica, disturbances caused by advance and retreat of the ice play a key role in structuring 

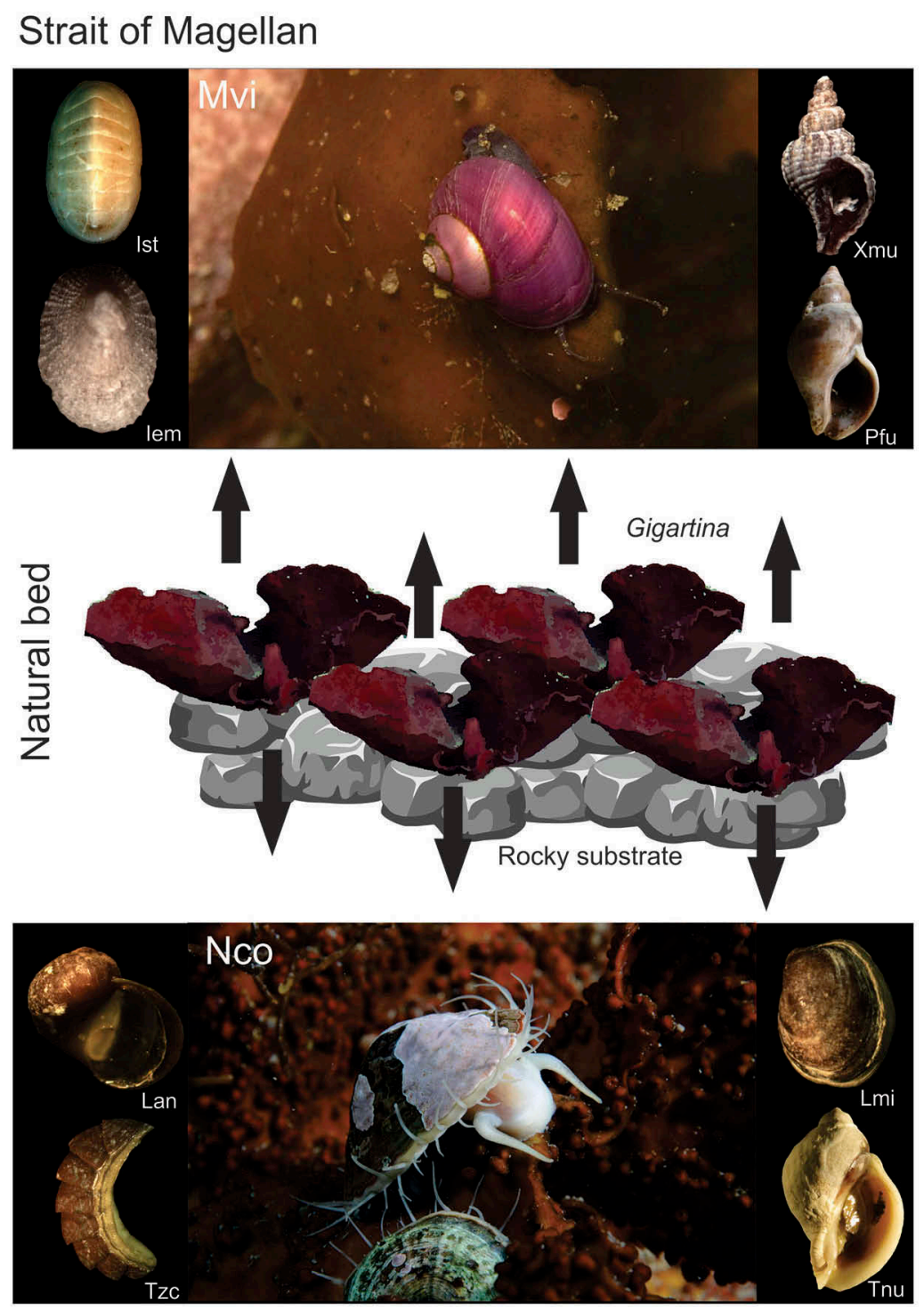

Antarctic Peninsula

Figure 6. Representative species found in Gigartina beds in the Strait of Magellan and South Shetland Islands. Iem (Iothia emarginuloides); for other abbreviated species names see labels of Fig. 3.

communities (Waller et al. 2006; Valdivia et al. 2015). Previous studies have shown that the highest diversities have been recorded in locations that undergo the greatest degree of physical disturbances by advancing ice (Waller et al. 2006), since all taxa present in these localities inhabit more specific habitats under boulders rather than on them. The presence of populations of macroalgae on the rocky coast of the Antarctic Peninsula should also contribute considerably as habitats for a variety of sessile and mobile fauna, since the creation and complexity of habitats that form the different macroalgae species play an important role in the formation of patterns of abundance and diversity of the communities associated with them (Torres et al. 2015; Valdivia et al. 2015). These patterns were observed by Martin et al. (2016) in populations of Adenocystis utricularis and Iridaea cordata around King George Island, by Amsler et al. (2015) in populations of eight dominant species of macroalgae and observed in this study in populations of Gigartina species on both sides of the polar front.

\section{Acknowledgments}

SR acknowledges the scholarship he received from Chile's Institute of Ecology and Biodiversity (code ICM P05-002) and the Master of Science in Conservation and Management of Sub-Antarctic Ecosystems of the University of Magellan. JM acknowledges the scholarship she received from Chile's Institute of Ecology and Biodiversity (code PFB -23-2008) and the Master of Science in Conservation and Management of SubAntarctic Ecosystems of the University of Magellan. We are grateful for the support of the Chilean Antarctic Institute (INACH) for sample collections in Antarctica. 
We thank the Chilean Navy Ships AP-46 Almte, Oscar Viel and AP-41 Aquiles for the resources and support offered during Antarctic field expeditions. The authors would like to thank the people of Patagonia Histórica S. A. for their valuable support to our fieldwork in Punta Santa Ana. We thank Dirk Schories for the photo of Nacella concina. The authors also thank two anonymous referees for their contribution in improving the manuscript.

\section{Disclosure statement}

No potential conflict of interest was reported by the authors.

\section{Funding}

This research was funded by Chile's National Council for Research in Science and Technology (CONICYT) FONDECYT Program grant 1140940 to AM, the Millennium Scientific Initiative (grant P05-002 ICM, Chile) and the Basal Financing Program (grant PFB-23, Chile). CA would like to thank the Program of Direction of Research and Graduate Studies of the University of Magallanes (code 027520, PR-01VRAC-14).

\section{ORCID}

Jaime Ojeda (D) http://orcid.org/0000-0003-3863-9750

\section{References}

Aghmich A., Taboada S., Toll L. \& Ballesteros M. 2016. First assessment of the rocky intertidal communities of Fildes Bay, King George Island (South Shetland Islands, Antarctica). Polar Biology 39, 189-198.

Aldea C., Rosenfeld S. \& Cárdenas J. 2011. Caracterización de la diversidad de moluscos bentónicos sublitorales en la isla Carlos III y áreas adyacentes, Estrecho de Magallanes, Chile. (Diversity characterization of subtidal benthic molluscs from Carlos III Island and adjacent areas, Strait of Magellan, Chile.) Anales del Instituto de la Patagonia 39, 73-89.

Amsler M.O., Huang Y.M., Engl W., McClintock J.B. \& Amsler C.D. 2015. Abundance and diversity of gastropods associated with dominant subtidal macroalgae from the western Antarctic Peninsula. Polar Biology 38, 1171-1181.

Anderson M.J. 2006. Distance-based tests for homogeneity of multivariate dispersions. Biometrics 62, 245-253.

Ávila A., Cáceres J., Nuñez M., Camus P., Pavez H., Cortes H., González J., Tapia C., Mejias P., Cornejo S., Romo H. \& Candia A. 2004. Investigación y manejo de praderas de luga roja en la XII Región. (Research and meadow management of Gigartina skottsbergii in the XII Region.) Valparaíso: FIP (Fund for Fishing Research) /IFOP (Institute of Fishing Promotion).

Ávila M., Candia A., Nuñez M. \& Romo H. 1999. Reproductive biology of Gigartina skottsbergii (Gigartinaceae, Rhodophyta) from Chile. Hydrobiologia 398/399, 149-157.

Bick A. \& Arlt G. 2013. Description of intertidal macroand meiobenthic assemblages in Maxwell Bay, King
George Island, South Shetland Islands, Southern Ocean. Polar Biology 36, 673-689.

Billard E., Reyes J., Mansilla A., Faugeron S. \& Guillemin M.-L. 2015. Deep genetic divergence between austral populations of the red alga Gigartina skottsbergii reveals a cryptic species endemic to the Antarctic continent. Polar Biology 38, 2021-2034.

Bowden D. 2005. Quantitative characterization of shallow marine benthic assemblages at Ryder Bay, Adelaide Island, Antarctica. Marine Biology 146, 1235-1249.

Castellanos Z.A. 1989. Catálogo descriptivo de la malacofauna marina Magallánica 4. Mesogastropoda. (Descriptive catalogue of marine Magellanic malacofauna. 4. Mesogastropoda.) La Plata: Buenos Aires Scientific Research Commission.

Christie H., Norderhaug K.M. \& Fredriksen S. 2009. Macrophytes as habitat for fauna. Marine Ecology Progress Series 396, 221-233.

Clarke A., Griffiths H.J., Linse K., Barnes D.K.A. \& Crame J.A. 2007. How well do we know the Antarctic marine fauna? A preliminary study of macroecological and biogeographical patterns in Southern Ocean gastropod and bivalve molluscs. Diversity and Distributions 13, 620-632.

Clarke K.R. 1993. Non-parametric multivariate analyses of changes in community structure. Australian Journal of Ecology 18, 117-143.

Clarke K.R. \& Gorley R. 2005. Primer-E v6. User manual/ tutorial. Plymouth: Plymouth Marine Laboratory, Natural Environmental Research Council.

Colwell R.K. \& Coddington J.A. 1994. Estimating terrestrial biodiversity through extrapolation. Philosophical Transactions of the Royal Society B 345, 101-118.

Engl W. 2012. Shells of Antarctica. Hackenheim; Germany: ConchBooks.

Fortes R.R. \& Absalao R.S. 2011. Biogeography and connectivity between western South American and Antarctic marine molluscs. Oecologia Australis 15, 111-123.

Gambi M., Lorenti M., Russo G. \& Scipione M. 1994. Benthic associations of the shallow hard bottoms off Terra Nova Bay, Ross Sea: zonation, biomass and population structure. Antarctic Science 6, 449-462.

Griffiths H.J., Barner D.K.A. \& Linse K. 2009. Towards a generalized biogeography of the Southern Ocean benthos. Journal of Biogeography 36, 162-177.

Griffiths H.J., Linse K. \& Crame J.A. 2003. Southern Ocean Mollusc Database: a tool for biogeographic analysis in diversity and ecology. Organism Diversity \& Evolution 3, 203-207.

Jazdzewski K., De Broyer C., Pudlarz M. \& Zielinski D. 2001. Seasonal fluctuations of vagile bentos in the uppermost sublittoral of a maritime Antarctic fjord. Polar Biology 24, 910-917.

Koleff P. 2005. Conceptos y medidas de la diversidad beta. (Concepts and measures of beta diversity.) In G. Halffter et al. (eds.): Sobre la diversidad biológica: el significado de las diversidades alfa, beta, gamma. (Biodiversity: the meaning of alpha, beta, gamma diversities.) Pp. 19-40. Zaragoza: Sociedad Entomológica Aragonesa.

Kruskal J.B. \& Wish M. 1978. Multidimensional scaling. Beverly Hills, CA: Sage Publications.

Linse K. 1999. Mollusca of the Magellan region: a checklist of the species and their distribution. Scientia Marina 63, 399-407.

Linse K., Griffiths H.J., Barnes D.K.A. \& Clarke A. 2006. Biodiversity and biogeography of Antarctic and subAntarctic mollusca. Deep-Sea Research Part II 53, 985-1008. 
Mansilla A. \& Ávila M. 2011. Using Macrocystis pyrifera (L.) C. Agardh from southern Chile as a source of applied biological compounds. Revista Brasileira De Farmacognosia 21, 262-267.

Mansilla A., Ávila M., Ramirez M., Rodriguez J.P., Rosenfeld S., Ojeda J. \& Marambio J. 2013. Macroalgas marinas bentónicas del submareal somero de la ecorregión Subantártica de Magallanes, Chile. (Shallow subtidal benthic marine macroalgae from the Magellan Subantarctic ecoregion, Chile.) Anales del Instituto de la Patagonia 41, 49-62.

Mansilla A., Rosenfeld S., Rendoll J., Murcia S., Werlinger C., Yokoya N. \& Terrados J. 2014. Tolerance response of Lessonia flavicans from the sub-Antarctic ecoregion of Magallanes under controlled environmental conditions. Journal of Applied Phycology 26, 1971-1977.

Martin P., Miloslavich P., Yusbelly D., Orteha I., Klein E., Troncoso J., Aldea C. \& Carbonini A.K. 2016. Intertidal benthic communities associated to the macroalgae Iridaea cordata and Adenocystis utricularis in King George's Island, Antarctica. Polar Biology 39, 207-220.

Moreno C.E. \& Halffter G. 2000. Assessing the completeness of bat biodiversity inventories using species accumulation curves. Journal of Applied Ecology 37, 149-158.

Pastorino G. 2016. Revision of the genera Pareuthria Strebel, 1905, Glypteuthria Strebel, 1905 and Meteuthria Thiele, 1912 (Gastropoda: Buccinulidae) with the description of three new genera and two new species from southwestern Atlantic waters. Zootaxa 4179, 301-344.

Quartino M.L., Zaixso H.E. \& Boraso de Zaixso A.L. 2005. Biological and environmental characterization of marine macroalgal assemblages in Potter Cove, South Shetland Islands, Antarctica. Botanica Marina 48, 187-197.

Ramírez E. \& Santelices B. 1991. Catálogo de las algas marinas bentónicas de la costa temperada del Pacífico de Sudamérica. (Catalogue of benthic marine algae of temperate Pacific coast of South America.) Santiago: Pontifical Catholic University of Chile.

Rau J., Zuleta C., Gantz A., Saiz F., Cortes A., Yates L., Spotorno A.E. \& Couve E. 1998. Biodiversidad de artrópodos y vertebrados terrestres del Norte Grande de Chile. (Biodiversity of arthropods and terrestrial vertebrates of Norte Grande, Chile.) Revista Chilena de Historia Natural 71, 527-554.

Ríos C., Arntz W.E., Gerdes D., Mutschke E. \& Montiel A. 2007. Spatial and temporal variability of the benthic assemblages associated to the holdfasts of the kelp Macrocystis pyrifera in the Straits of Magellan, Chile. Polar Biology 31, 89-100.

Ríos C., Mutschke E. \& Morrison E. 2003. Biodiversidad bentónica sublitoral en el estrecho de Magallanes, Chile. (Benthic sublittoral biodiversity in the Strait of Magellan, Chile.) Revista de Biología Marina y Oceanografía 38, 1-12.

Rosenfeld S., Aldea C., Mansilla A., Marambio J. \& Ojeda J. 2015. Richness, systematics and distribution of molluss associated with the macroalga Gigartina skottsbergii, in the Strait of Magellan, Chile: a biogeographic affinity study. Zookeys 519, 49-100.

Rosenfeld S., Ojeda J., Hüne M., Mansilla A. \& Contador T. 2014. Egg masses of the Patagonian squid Doryteuthis
(Amerigo) gahi attached to giant kelp (Macrocystis pyrifera) in the sub-Antarctic ecoregion. Polar Research 33, article no. 21636, doi: 10.3402/polar.v33.21636.

Rueda J.L. \& Salas C. 2003. Seasonal variation of a molluscan assemblage living in a Caulerpa prolifera meadow within the inner Bay of Cádiz (SW Spain). Estuarine Coastal and Shelf Science 57, 909-918.

Salas C. \& Hergueta C. 1986. La fauna de moluscos de las concreciones calcáreas de Mesophyllum lichenoides (Ellis) Lemoine. Estudio de la diversidad de un ciclo anual. (The molluscan fauna of Mesophyllum lichenoides [Ellis] Lemoine calcareous concretions. Study of the diversity of an annual cycle.) Iberus 6, 57-65.

Sánchez-Moyano J.E., Estacio F.J., García-Adiego E.M. \& García-Gómez J.C. 2000. The molluscan epifauna of the alga Halopteris scoparia in southern Spain as a bioindicator of coastal environmental conditions. Journal of Molluscan Studies 66, 431-448.

Soberón J. \& Llorente J. 1993. The use of the species accumulation functions for the prediction of species richness. Conservation Biology 7, 480-488.

Spalding M.D., Fox H.E., Allen G.R., Davidson N., Ferdaña Z.A., Finlayson M., Halpern B.S., Jorge M.A., Lombana A., Lourie S.A., Martin K.D., McManus E., Molnar J., Recchia C.A. \& Robertson J. 2007. Marine ecoregions of the world: a bioregionalization of coastal and shelf areas. Bioscience 57, 573-583.

Stachowicz J.J. 2001. Mutualism, facilitation, and the structure of ecological communities. Bioscience 51, 235-246.

StatSoft. 2004. Statistica for windows. Computer program manual. Tulsa, OK: StatSoft Inc.

Torres A.C., Veiga P., Rubal M. \& Sousa-Pinto I. 2015. The role of annual macroalgal morphology in driving its epifaunal assemblages. Journal of Experimental Marine Biology and Ecology 464, 96-106.

Vahl O. 1971. Growth and density of Patina pellucida (L.) (Gastropoda: prosobranchia) on Laminaria hyperborea (Gunnerus) from western Norway. Ophelia 9, 31-50.

Valdivia N., Díaz M.J., Garrido I. \& Gómez I. 2015. Consistent richness-biomass relationship across environmental gradients in a marine macroalgal-dominated subtidal community on the western Antarctic Peninsula. Plos One 10, e0138582, doi: 10.1371/journal. pone.0138582.

Valdovinos C. 1999. Biodiversidad de moluscos chilenos: base de datos taxonómica y distribución. (Chilean mollusks biodiversity: taxonomic and distributional data base.) Gayana 63, 111-164.

Waller C.L., Barnes D.K.A. \& Convey P. 2006. Ecological contrasts across and Antarctic land-sea-interface. Austral Ecology 31, 656-666.

Whittaker R.H. 1972. Evolution and measurement of species diversity. Taxon 21, 213-251.

Wiencke C. \& Clayton M.N. 2002. Synopses of the Antarctic benthos. Vol. 9. Antarctic seaweeds. Ruggell, Lichtenstein: Gantner.

Zelaya D.G. 2005. Systematics and biogeography of marine gastropods molluscs from South Georgia. Spixiana 28, 109-139. 